\title{
Office of Biological Informatics and Outreach Geospatial Technology Activities
}

The U.S. Geological Survey (USGS) Office of Biological Informatics and Outreach (OBIO) in Reston, Virginia, and its Center for Biological Informatics (CBI) in Denver, Colorado, provide leadership in the development and use of geospatial technologies to advance the Nation's biological science activities.

\section{Cartographic Data Needs (USGS A-16 Program)}

The Federal Geographic Data Committee (FGDC) and other National Spatial Data Infrastructure (NSDI) activities were mandated under Office of Management and Budget Circular A-16, which directs the USGS to gather high-priority base cartographic data requirements from Federal and State agencies. CBI serves as the Biological Resources Division (BRD) coordination point for this process, through which BRD science program needs are merged with other Federal and State needs.

$<$ http://biology.usgs.gov/cbi/programs/a-16.html >

Contact: Maury Nyquist, 303/202-4217

(maury_nyquist@usgs.gov)

\section{Gap Analysis Program (GAP)}

The Gap Analysis Program provides State, regional, and national assessments of the conservation status of native vertebrate species and natural land cover types. This information is made available to land managers, planners, scientists, and policy makers to help them make informed land management decisions. More than 450 Federal, State, and local groups are included in the GAP partnership, which is coordinated by CBI.

$<$ http://www.gap.uidaho.edu/gap/>

Contacts: Mike Jennings, 208/885-3565

(mike jennings@usgs.gov)

John Mosesso, 703/648-4079

(john_mosesso@usgs.gov)

\section{Geospatial Technology Program}

The Geospatial Technology Program provides national coordination for the use and application of geographic information systems, remote sensing technologies, satellite positioning systems, telemetry, and thematic mapping in accordance with the BRD Geospatial Technology Strategic Plan (USGS/BRD/ITR-1997-0003). Geospatial Technology Coordinators representing BRD centers and programs work together to support National Biological Information Infrastructure (NBII) metadata and clearinghouse activities, geospatial technology training, and a variety of research applications.

$<\mathrm{http} / /$ biology.usgs.gov/geotech/>

Contact: James Getter, 301/286-8635

(james_getter@usgs.gov)

\section{Global Positioning System (GPS)}

The Global Positioning System is a constellation of satellites that send radio signals from space and Earth-based control and monitoring stations. These signals are interpreted through handheld receivers to determine the location of points on Earth. Working with the Department of Defense, CBI serves as the coordination point for encryption of codes in Department of the Interior (DOI) receivers that provide the military level of positioning accuracy, thus greatly increasing the value of this information to the scientific research community. Center staff also provide DOI users with GPS technology information and training.

$<\mathrm{http}$ //biology.usgs.gov/gps/index.htm >

Contact: Karl Brown, 303/202-4240

(karl_brown@usgs.gov)

\section{Land Use History of North America (LUHNA)}

Understanding the relationships between human land use and land cover change and assessing implications for the future are the goals of the Land Use History of North AmericaLUHNA - project. Along with assembling a history of land use and environmental change, LUHNA is producing related data products and analytical tools. This multi-discipline national project is guided by CBI, with participation by public and private research organizations, educational institutions, grant makers, and the public.

$<$ http://biology.usgs.gov/luhna/>

Contact: Maury Nyquist, 303/202-4217

(nyquist_maury@usgs.gov)

\section{National Biological Information Infrastructure}

The National Information Infrastructure (NII) is an interconnection of computers and telecommunication networks, services, and applications. As the biological component of this "information superhighway," the NBII provides information on and access to biological data and information through an electronic federation of sources-a growing network of Federal, State, and local government, university, and private-sector partners who share biological information. The NBII is linked to the NSDI, the NII component that focuses on geospatial data. Whenever biological data included in the NBII federation have an explicit geospatial component, all relevant NSDI standards and policies are followed.

$<$ http://www.nbii.gov/>

Contact: Anne Frondorf, 703/648-4205

(anne_frondorf@usgs.gov)

NBII Metadata Content Standard

Metadata — data elements that describe other data—serve as 
the card catalog in the NBII library of biological data and information. The NBII has developed a biological superset of the FGDC standard for metadata documentation, to be used as the basis for the card catalog for biological data and information of all types, including geospatial information. <http://www.nbii.gov/current.status.html>

Contact: Susan Stitt, 303/202-4234

(susan_stitt@usgs.gov)

\section{NBII Metadata Clearinghouse}

The NBII Metadata Clearinghouse contains standardized metadata-based descriptions of biological datasets and information products, serving as a pointer to biological data and information provided by a distributed network of partners. Metadata descriptions follow the NBII's biological profile of the FGDC Content Standard for Digital Geospatial Metadata. The NBII Clearinghouse is also a participating node on the FGDC National Spatial Data Clearinghouse. OBIO staff coordinate the NBII Clearinghouse operation and content. $<$ http://www.nbii.gov/clearinghouse.html >

Contact: Susan Stitt, 303/202-4234

(susan_stitt@usgs.gov)

\section{Metadata training}

OBIO staff provide training in and consultation on the use of MetaMaker, a Windows application designed by BRD for recording metadata information in a standardized format. Workshops cover metadata and NBII Clearinghouse concepts, NBII/FGDC metadata structure and content, NBII

Clearinghouse use, and metadata development and

consistency issues. Workshops are open to Federal, State, and local government agencies, as well as to other potential data sharers. Assistance in metadata encoding is provided as resources are available.

$<$ http://www.nbii.gov/metamaker/metamaker.html>

<ftp://ftp.cbi.usgs.gov/pub/nbii/nbiiwbk.wpd>

Contacts: Sharon Shin, 303/202-4230

(sharon_shin@usgs.gov)

Jennifer Gaines, 703/648-4208

(jennifer_gaines@usgs.gov)

\section{National Geospatial Technology Committees}

OBIO staff represent the biological community on a variety of geospatial technology committees that address policy and standards development and implementation. Through these activities, biologists are provided with the means to link biological data with pertinent geospatial information.

Contacts: James Getter, 301/286-8635

(james_getter@usgs.gov),

Maury Nyquist, 303/202-4217

(maury_nyquist@usgs.gov)

Committees and subgroups

- Coast Guard Civil GPS Service Interface Committee

- DOI-National Aeronautics and Space Administration Hyperspectral Imaging Technical Transfer Project

- Federal Geographic Data Committee -Base Cartographic Subcommittee -Geodetic Control Subcommittee
-Vegetation Subcommittee

-Biological Data Working Group

-Clearinghouse Working Group

-Earth Cover Working Group

-Standards Working Group

- GPS Interagency Advisory Council

- Interior Geographic Data Committee

-Base Mapping Working Group

-Remote Sensing Working Group

- National Spatial Data Applications Consortium

- USGS Geographic Data Committee

-Clearinghouse Working Group

-Remote Sensing Working Group

-Requirements Working Group

-Standards Working Group

\section{National Technical Means Program}

Through the National Technical Means Program, CBI staff assist USGS and other civilian agency personnel requiring access to classified data and technologies. Assistance is coordinated through the Civil Applications Committee, which reports to the Director of the Central Intelligence Agency.

<http://biology.usgs.gov/cbi/programs/ntm.html>

Contact: James Getter, 301/286-8635

(james_getter@usgs.gov)

\section{USGS-NPS Vegetation Mapping Program}

Since 1993, a partnership has been maintained with the National Park Service (NPS) to develop uniform, consistent baseline data on the composition and distribution of vegetation communities in approximately 250 NPS units. The methods and standards developed for the program have been adopted by other vegetation mapping projects. CBI coordinates the program and directs its scientific activities, carried out by DOI agencies and the private sector.

$<$ http://biology.usgs.gov/npsveg>

Contacts: Tom Owens, 303/202- 4259

(tom_owens@usgs.gov)

Ralph Root, 303/202-4232

(ralph_root@usgs.gov)

\section{Additional Information}

U.S. Geological Survey

Biological Resources Division

Office of Biological Informatics and Outreach, M.S. 300

12201 Sunrise Valley Drive

Reston, Virginia 20192

email:james_getter@usgs.gov

U.S. Geological Survey

Biological Resources Division

Center for Biological Informatics, M.S. 302

Building 810, Denver Federal Center

Denver, Colorado 80225

email: mark_fornwall@usgs.gov 